\title{
ADMISSIBILITY OF FACT OF SUBMISSION TO LIE DETECTOR TEST*
}

\begin{abstract}
A NOVEL question in regard to the admissibility of lie detector evidence was raised in the recent case of Kaminski $v$. State. ${ }^{1}$ In a trial for assault with intent to murder, the State was forced to rely on the testimony of one Newbold, the prosecuting witness, to establish both the defendants' motives and their presence at the scene of the crime. Following his cross-examination, which was at variance with the testimony of other witnesses for the State, the State sought to rehabilitate Newbold's direct testimony. Pursuant to this objective, he was asked in the course of redirect examination whether he had taken a lie detector test prior to trial. An objection to this question was made and overruled with permission being given to either side to introduce the results of the test. After Newbold acknowledged having taken the test, however, neither the State nor the defense sought to introduce its results. The defendants were convicted. On appeal the verdict was affirmed, but upon rehearing it was reversed on the ground that it was error to admit evidence that the prosecuting witness had taken a lie detector test.
\end{abstract}

Results of lie detector tests have uniformly been denied admission into evidence by courts of appeal, ${ }^{2}$ with only rare exceptions to be found in the lower courts. ${ }^{3}$ Principally, this evidence is rejected on

* Kaminski v. State, 63 So.2d 339 (Fla. 1953).

${ }^{1} 63$ So.2d 339 (Fla. r953).

2Frye v. U.S., 293 Fed. ror 3,34 A.L.R. 145 (D.C. Cir. 1923); People v. Wochnick, 98 Cal. App. 2d 124, 2 19 P.2d 70 (1950); State v. Lowry, 163 Kan. 622, 185 P.2d I47 (1947); Stone v. Earp, 33r Mich. 606, 50 N.W.2d I72 (r95I) (inadmissible even in civil case); People v. Becker, 300 Mich. 562, 2 N.W.2d 503, I39 A.L.R. I I7I (1942); State v. Kolander, 236 Minn. 209, 52 N.W.2d 458 (I952); State v. Cole, 354 Mo. I8I, r88 S.W.2d 43, I89 S.W.2d 54r (1945); Boeche v. State, I 5 I Neb. 368,37 N.W.2d 593 (1949); People v. Forte, 279 N.Y. 204, I 8 N.E.2d 3I, II9 A.L.R. II98 (I939); State v. Pusch, 77 N.D. 860, 46 N.W.2d 508 (1950); Leeks v. State, 245 P.2d 764 (Okla. Crim. App. 1952); Henderson v. State, 230 P.2d 495, 23 A.L.R.2d 1292 (Okla. Crim. App. I95I); Peterson v. State, 247 S.W.2d I 10 (Tex. Crim. App. 1952); Le Fevre v. State, 242 Wis. 416, 8 N.W.2d 288 (r943); State v. Bohner, 210 Wis. 65 I, 246 N.W. 3I4, 86 A.L.R. 6Ir (1933); 20 AM. Jur., Evidence $\S 762$ (1939); 3 Wigmore, Evidence $\$ 999$ (3d ed. 1940).

${ }^{3}$ People v. Kenny, 167 Misc. 5 I, 3 N.Y.S.2d 348 (Queens Co. Ct. 1938) (lie detector evidence admissible where proper foundation laid as to the accuracy of device, expert witness testifying as to infallibility of his lie detector.) See, however, Inbau, The Lie Detector, 26 B.U.L. REv. 264, 268 (1946), according a lesser degree of 
grounds that the reliability of the lie detector has not attained sufficient recognition among scientists. ${ }^{4}$ Thus, if either party in the Kaminski case had taken full advantage of the court's ruling by seeking to introduce into evidence the results of the test, their admission over objection would have been held error in the courts of last resort in all jurisdictions which have passed on the question.

In the principal case, as has been noted, however, the State made no effort to introduce the results of the test, but merely endeavored to show that a test had been taken. The inference probably intended to be drawn from this fact was that Newbold would not have submitted voluntarily to the test had he not been veracious, and that his direct testimony, therefore, was credible despite the subsequent conflicting testimony presented by the state. Any such inference undoubtedly would be reinforced by failure of the defendants to introduce the results of the test.

This appears to be the first case in which an appellate court has ruled on the admissibility of the bare fact, as distinguished from the results, of a lie detector test, offered for the purpose of sustaining the credibility of a witness. ${ }^{5}$ Although strong arguments have been ad-

accuracy to the instrument. In People v. Forte, supra note 2, the New York Court of Appeals ruled lie detector evidence inadmissible. See also, People v. Houser, 85 Cal. App. 686, 193 P.2d 937 (1948). (defendant who had agreed to take test and admit results and who had stipulated that operator was an expert estopped to deny admissibility.)

"This was the view of the court in Frye v. United States, note 3 supra, the first case involving lie detector evidence, wherein the court said: "We think the systolic blood pressure deception test has not yet gained such standing and scientific recognition among physiological and psychological authorities as would justify the courts in admitting expert testimony deduced from the discovery, development, and experiments thus far made." 293 Fed. 1013 , 1014, 34 A.L.R. 145, 146 (D.C. Cir. 1923). For an extensive discussion of this point in a recent case, see Henderson v. State, 230 P.2d 495, 23 A.L.R.2d 1292 (Okla. Crim. App, 1951).

One of the leading experts in this field, Professor Inbau, accords an accuracy of about seventy-five percent to the lie detector. Inbau, The Lie Detector, 26 B.U.L.REv. 264,268 (1946). For a survey of both legal and scientific aspects of lie detection, see Inbau, Lie Detection and Criminal. Interrogation (2d ed. 1948). A bibliography of material on lie detection prior to 1943 may be found in Note, I943 WIs. L. REv. 430, 444 .

'An analogous question was raised, however, in a recent Minnesota case where the appellate court held that the trial court erred in allowing the State to introduce evidence that the defendant had refused to take a lie detector test as evincing his consciousness of guilt. State v. Kolander, 236 Minn. 209, 52 N.W.2d 458 (1952), in which the court relied on People v. Wochnick, 98 Cal. App. 2d 124, 219 P.2d 70 (1950), which held that the results of such tests were not admissible indirectly in an accusatory statement by a police officer to the effect that the lie detector indicated a violent reaction when defendant was confronted with the murder weapon. 
vanced for admitting the results of lie detector tests, ${ }^{6}$ if the rationale of the courts in rejecting them ${ }^{7}$ is accepted, it would seem equally applicable where the admissibility of the mere fact of taking the test is in issue. It is improbable that any jury which hears evidence that a party or witness has submitted to a lie detector test will fail to draw some inference as to its results, no matter how vehement the court's cautionary instruction. If the courts will not receive the results of lie detector tests in evidence because of uncertainty as to their scientific reliability, they should not encourage juries to infer these results. Indeed, compounding the danger of the unreliability of these results would be the danger that juries would draw incorrect and unwarranted inferences therefrom. As a matter of logical consistency, therefore, the decision of the appellate court in this case was both inevitable and proper.

\section{S. Perry Keziah}

The most frequent argument in support of admission of lie detector evidence is that where a proper foundation as to the efficacy and limitations of the instrument has been laid, the jury should be allowed to weigh these results along with other evidence bearing upon the guilt or innocence of a defendant. See the concurring opinion in Boeche v. State, I5 I Neb. 368, 378, 37 N.W.2d 593, 597 (1949). See also People v. Kenny, 167 Misc. 51, 3 N.Y.S.2d 348 (Queens Co. Ct. 1938). Several unreported cases in which lie detector evidence was admitted have been noted in Note, I943 W1s. L. REv. 430 .

\footnotetext{
${ }^{7}$ Supra note 4 .
} 